\title{
Impact of inflation on import: An empirical study
}

\author{
Md. Ariful Islam \\ BASIC Bank Limited, Khulna, Bangladesh
}

Email address:

arifrussell@yahoo.com

To cite this article:

Md. Ariful Islam. Impact of Inflation on Import: An Empirical Study. International Journal of Economics, Finance and Management Sciences. Vol. 1, No. 6, 2013, pp. 299-309. doi: 10.11648/j.ijefm.20130106.16

\begin{abstract}
Inflation is associated with rising price. It is a situation in which there is a sustained, inordinate (excessive), and general increase in prices. The increase in prices must last for a reasonable period of time. If prices go up during this period and fall in the next, then it is mere price fluctuation. The increase in price must be excessive by that country's experience. Inflation is the rise in average price of all goods that we buy and not just of one item. After analyzing the trend of inflation rate, number of $\mathrm{L} / \mathrm{C}$ and value of $\mathrm{L} / \mathrm{C}$ opened in Prime Bank Limited, Khulna Branch in the last five years, it is seen that there is a minimum or very insignificant correlation between inflation and import trade. Theoretically, there is a positive correlation between domestic inflation and import. This study also shows a positive correlation, but the correlation is very insignificant. Obviously, there are some reasons behind this insignificance. We should remember that, inflation is not the only factor that can affect the import trade. There are many other factors that can influence the import trade of a country. In case of Bangladesh, the reasons are the massive pressure on the demand of goods available, exchange rate fluctuation, huge population, frequent natural disasters of Bangladesh, different government policies, relationship with the exporting country, inflation rate of the exporting country etc. As so many factors are influencing the import of a country, that's why inflation cannot create a huge pressure on the import.
\end{abstract}

Keywords: Inflation, Import, Letter of Credit, Exchange Rate, Consumer goods, Trade, GDP

\section{Introduction}

\subsection{Background of the Study}

Inflation is a rise in the general level of prices of goods and services in an economy over a period of time. When the general price level rises, each unit of currency buys fewer goods and services. Consequently, inflation also reflects an erosion in the purchasing power of money - a loss of real value in the internal medium of exchange and unit of account in the economy. A chief measure of price inflation is the inflation rate, the annualized percentage change in a general price index (normally the Consumer Price Index) over time.

\subsection{Rationale of the Study}

Banks are special types of financial institutions, which make money from money. The basic job of a bank is to collect money at a lower interest rate from those who have surplus amount of money and then disburse it to the people who have a need of money at a higher interest rate. Besides this, banks play a vital role in foreign trade.

Trading with foreign companies is next to impossible without the direct intervention of banks. Inflation rate is one of the key factors that can affect the decision in foreign trade. This report tries to clarify the impact of inflation rate on import trade. This report analyzes the fluctuation of inflation rate in different quarters of the last five years and the trend of import $\mathrm{L} / \mathrm{C}$ at those quarters. Such discussion may help in taking important decisions about import trade.

\section{Literature Review and Conceptual Framework}

\subsection{Inflation}

Definition of Inflation has been different in different dictionaries over the ages. Though those definitions are not same but the key concepts of all the definitions are same, and that is the price increase of daily necessities. To understand inflation, we first need to understand what the word means. The Economics Glossary defines Inflation as:

Inflation is an increase in the price of a basket of goods and services that is representative of the economy as a whole. A similar definition of inflation is found in Economics by Parkin and Bade: 
Inflation is an upward movement in the average level of prices. Its opposite is deflation, a downward movement in the average level of prices. The boundary between inflation and deflation is price stability.

Here is some other definition of inflation: Inflation is an economic condition wherein the price of the goods and services increase steadily measured against standard level of purchasing power, whereas the supply of the goods and services decline along with the devaluation of money. (economywatch.com)

Inflation is associated with rising price. It is a situation in which there is a sustained, inordinate (excessive), and general increase in prices. There is a continuous fall in the value of money as there is too much money chasing after too few goods. The increase in prices must last for a reasonable period of time. If prices go up during this period and fall in the next, then it is mere price fluctuation. The increase in price must be excessive by that country's experience. Inflation is the rise in average price of all goods that we buy and not just of one item.

Inflation may be classified according to the rate of increase in prices. The 'rate of inflation' is the percentage increase in the Retail Price Index (RPI) over the period of one year. (searchwarp.com)

Inflation is a broad increase in prices. In practical terms, inflation means goods and services are being valued as more desirable than money. This also affects wages; periods of high inflation tend to be marked by increases in average income. (dogsofthedow.com)

The measure of price increases within a set of goods and services over a period of time is known as inflation. (mysmp.com)

Inflation is when prices continue to creep upward, usually as a result of overheated economic growth or too much capital in the market chasing too few opportunities. Usually wages creep upwards, also, so that companies can retain good workers. Unfortunately, the wages creep upwards more slowly than do the prices, so that your standard of living can actually decrease. (about.com)

Inflation- A general increase in prices in an economy and consequent fall in the purchasing value of money. (Oxford Business Dictionary)

Inflation is an increase in the amount of money and credit in relation to the supply of goods and services. Often, inflation is erroneously defined by the effect that it has on the economy. When people notice that gas, food, and lodging is getting more expensive, they often label that phenomenon inflation. Rising prices, however, are really just the result of inflation. Over time, as the cost of goods and services increase, the value of money is going to fall because a person won't be able to purchase as much with that money as he/she previously could.

\subsection{Reasons of Inflation}

Depending upon the reason of inflation, it can be divided in many types as

Demand-Pull inflation: This represents a situation where there is increase in Aggregate Demand for resources either from the government or the entrepreneurs or the households. Result of this is that the pressure of Demand can't be met by the currently available Aggregate Supply which results in Aggregate Demand > Aggregate Supply which is bound to generate inflationary pressure in the economy.

Cost-Push inflation: This represents the condition where even though there is no increase in Aggregate Demand, prices may still rise. This may happen if the costs, especially wages cost rise.

Structural inflation: This type of inflation occurs because of change in structure of economies as happened in India from Agricultural Structure i.e. Green Revolution to Industrialization. Thus because of change in Economic Structure gives rise to increase in prices thus generate inflationary pressure.

\subsection{Characteristics of Inflation}

From the above information we can find out the following characteristics of inflation;

General increase in the price of goods and services.

Price of products and services' related only with daily necessities are calculated.

Price increase of a basket of goods not a single or two items.

Increased price must last for a reasonable period of time.

Reduces purchasing power.

Devaluation of money that, value of commodity goes over the value of currency. Sustained increase in price

Therefore, when price increases for a basket of daily necessities for a reasonable period of time then it is called inflation. If the price of only one or two items increased that is not called inflation. Again, the price increase for a shorter period of time should be said price fluctuation not inflation.

\subsection{Causes of inflation in Bangladesh}

Economists, policy makers and multilateral capital donors have different explanations about the causes of inflation in countries like Bangladesh. A brief look at a few of such explanations merits attention for shaping and re-shaping of appropriate policies to help curb inflation. Here below is a brief critical overview of such explanations.

One of the causes of inflation, explained as such, relates to food prices in the international market. Bangladesh being a food importing country, any rise in food prices in the world market can push up the domestic prices of those commodities. In the not too distant past, the prices of essential commodities, like rice, wheat and edible oil, increased significantly in the international markets. So, domestic prices of those items shot up phenomenally then.

Then the link between rising prosperity and inflation is sought to be proved by many. Despite all its problems, Bangladesh has been performing well, in terms of economic growth over the last 10 years. Its gross domestic product (GDP) base is not small, in absolute volume terms. It is the 50th largest economy in a sample of 177 countries. Not 
many developing countries have grown faster than Bangladesh with bigger GDP volumes since the early 1990s. Those who seek to link inflation and GDP growth performance state that the high growth rate of GDP and the per capita GDP in particular has led to the creation of excess demand in the Bangladesh economy. This has resulted in a demand-pull inflation (Mortaza M. G 2006).

Then there is the growth of money supply that is directly related to the price situation. 'Inflation is a monetary phenomenon', so is explained by a good number of economists as well as some of the donor agencies. It is, thus, stated to be caused by the excessive supply of money in the economy. Bangladesh Bank has otherwise been found to be guided by the monetarist approach to inflation -- and that is not without some good reason. It has been following a rather "cautious" monetary policy. Many consider it as a pragmatic step (Shahiduzzaman, 2006).

Then the question of relative strength of Bangladesh currency in relation to those of other countries, particularly that of neighboring India, is considered an issue of consequence for analyzing the price situation here. The Bangladeshi taka has depreciated to some extent against its intervention currency, US dollar over the past several years. But the Indian rupee has depreciated higher than that. As a result, the relative position of the Bangladesh currency has suffered, having its impact on the economy because India is Bangladesh's major source of import, through both formal and informal channels. Imports from India in recent years constitute more than 20 per cent of Bangladesh's total imports, comprising many essential food items.

If the import cost for Bangladesh is affected by the cross-currency exchange rates, this affects the prices. Any movement of prices in the upward direction indicates depreciation of taka relative to the currency in question after adjusting for inflation. This hypothesis does also provide some reasonably plausible explanation to the movements of prices of essential food items in Bangladesh. However, there are some disagreements among the economists and policymakers with regard to combating this situation. The policy of foreign reserve accumulation by the Bangladesh Bank is considered by some quarters as not being consistent with the exchange rate movements of taka vis-a-vis the Indian rupee in recent years.

Fuel prices is yet another factor that is cited to have a major impact on the domestic price situation. If the fuel prices go up, that impacts the prices of commodities through two major channels: the high prices of fuels lead to high cost for irrigation, which raises the cost of agricultural production; and, high fuel prices increase the cost of transportation, which also raises the prices of essential items transported from remote villages to urban areas.

The non-competitive market features or what are stated to be "the syndicate" syndrome are otherwise widely considered as being one of the strong factors, igniting price pressures. Here, argument is made about many middle-men, wholesalers and importers acting as syndicates and causing large price hikes, by making cartels and hoarding essential goods like rice, wheat and edible oil. Such cartels do reportedly fix the prices of these goods, dictate supply in the market, and earn excess profits (Mortaza, 2006).

However, there is yet no convincing, concrete evidence of 'syndicates' being in total control of the markets of essential commodities to take advantage of the weak consumer protection laws. However, some short-term alliances among the suppliers of such goods are not to be rule out to have some influence over supply and prices. This may have some impact on the rising prices of essential items.

Then the issue of growth of remittances and its links with inflation come. There has been a steady and substantial rise in remittance inflow over the last few years. Such inflow does, no doubt, contribute to demand-pull inflation in Bangladesh. Working as the Rising Prosperity Hypothesis (Rahman H. and Mortaza M. G. 2008), such demand-pull factors can push up prices. However, increased remittance inflow alone is unlikely to be a major cause of inflation. This is so because the rise in demand has been supported by the rise in supply through increased imports.

\subsection{Inflation and Import Trade in Bangladesh}

Bangladesh economy has been experiencing higher inflation of import-concentrated commodities especially of food items indicating the dominance of higher food prices in the international market in raising recent inflation in Bangladesh.

In estimating inflation rates of import-concentrated commodities, it is important to find out the links through which domestic inflation may be affected by imports or higher prices of commodities at the international market. Since a large portion of final consumption goods and services in Bangladesh are, either directly or indirectly, based on imports, it is expected that higher prices of those goods in the international markets may directly transmit to the domestic prices unless there are strong substitutes of those goods in the domestic market. "Even if there are strong substitutes of imported commodities, higher inflation of commodities in the international market may push up prices of domestic substitutes of those commodities if the supply is fixed in the wholesale market and the demand increases due to higher prices of imported commodities. Moreover, if the prices of imported inputs are used in the production of final domestic commodities, the production cost will increase and eventually, the prices at the farm gate level and the ultimate selling price will increase as well" (Rahman M. 2010). Thus prices of import items may have differential impact on final consumer prices in the domestic market and call for estimating the role of imported inflation to overall domestic inflation.

In an open economy, transmission of trading partners' inflation to the domestic economy is one of the aspects how domestic inflation may be fuelled up. In fact, recent inflationary period of Bangladesh is mostly explained by a surge in prices of commodities at the global market on which Bangladesh is highly dependent for final consumption. And as a small open economy and a net importer of food 
commodities, the Bangladesh economy needs to accept higher prices of world food commodities. Similar trends have also been observed in the case of non-food commodities as large amount of capital machinery and raw materials for some leading exporting industries such as ready-made garments (RMGs) in Bangladesh are also imported from abroad (Akhtaruzzaman Md. 2005).

The transmission of trading partners' inflation to the domestic economy can be both direct and indirect. In the direct way, higher prices of imported consumer goods and inputs may quickly transmit to the domestic economy. However, domestic inflation and higher prices of imported commodities and raw materials are connected in several ways. First, domestic inflation of final consumer goods may increase directly due to higher prices of those items at the international market. It is expected that higher prices at the production level in abroad due to higher prices of inputs such as oil and labor, may increase the prices of final products in abroad and the imports of those commodities to the domestic market will eventually increase the consumer prices at the domestic market. Lower agriculture production in abroad due to natural disasters such as drought or the increase of use in cropland for other production purposes may create a situation of excess demand among countries, which can have a positive shock on prices of those commodities in the international market and eventually will push the domestic consumer prices to go up. The higher freight charge or higher transportation cost of imported items due to higher prices of oil may add to the final consumer prices in the domestic market. In a similar fashion, higher tariff rate on imported items will put an upward pressure on the selling price in the domestic market (Farah and Mortaza 2009).

In the indirect way, for example, if China's inflation rate is higher than in Bangladesh, then it is rationale for traders to take advantage of price differentials, or arbitrage. Arbitrage will increase the demand for tradable items in Bangladesh, and hence raise domestic prices (Taslim and Chowdhury 1995). Moreover, higher price of imported inputs for domestic export sector may increase the price of exports. A rise in export price directly improves the earnings of the exporters which will result in increased expenditure and will cause a demand-pull type of inflation. An improvement in export earnings also may encourage the exporters to import more raw materials from abroad for their production and the resulting outcome will be a further rise of inflation.

One may term the above as structural inflation and stress on structural rigidities of the economy as the principal cause of inflation (Jhingan 1997). The process starts with the increase in non-agricultural incomes at the initial phase of development accompanied by high growth of population that tends to increase the demand for goods. More specifically, as the demand for agricultural goods rises with their domestic supply inelastic, prices of agricultural goods rise. The output of these goods doesn't increase with the pace of their price rise due to a defective system of land tenure and other rigidities in the form of lack of irrigation, finance, storage and marketing facilities, and bad harvests. As imports in large quantities are hampered due to foreign exchange constraints and the prices of imported products are relatively higher than their corresponding domestic prices, the process pushes the domestic price level to rise.

In another indirect channel, prices of domestic substitutes will increase due to higher prices at the international market, mainly due to two reasons. First, if the supply of that commodity is fixed in the wholesale market, the demand for domestic substitutes will increase due to higher prices of imported commodities. Second, the production of substitute goods may take a long period which will put pressure on demand of existing availability of those commodities. The resulting effect in either of the above cycles is higher prices of domestic substitutes of imported commodities (Rahman M. 2010).

Thus, trading partners' inflation may have differential impact on domestic inflation and may fuel up domestic inflation. At the aggregate level, the channel through which the effect of international price changes is reflected in domestic inflation is the direct relationship between consumer price index (CPI) and import price index (IPI). If commodity prices at the international market rise, it will be reflected in IPI and consequently will affect domestic CPI.

However, this note identifies indirect channels as well higher input price or substitution effect - through which imported price may affect domestic prices. Thus we call the underlying estimated inflation rates as 'inflation rates of import-concentrated commodities' rather than 'imported inflation.'

From the above discussion, it is seen that my report topic is little discussed previously in context of Bangladesh. So far, I know this is quite new study concept and not researched previously. Therefore, I think, this report will add some value to the corresponding parties.

\section{Materials and Methods}

\subsection{Research Questions}

Research questions have been developed after assessing the existing literature and also evaluating the contexts of local businesses and market set-up. In the process of setting the research questions -the prospective future contribution of this research work also has been considered. That was a major concern because the study should be able to contribute something in the existing scientific literatures and also for the development of the country and society. The following research questions have been set afterwards:

Research Question 1: Is it reasonable to infer that inflation has positive effect on opening number of import $\mathrm{L} / \mathrm{Cs}$ ?

Research Question 2: Is it reasonable to conclude that inflation has positive effect on volume of import L/Cs?

Research Question 3: Is it reasonable to infer that rate of inflation determine the import business positively or negatively? 


\subsection{Sources of Information}

The study is conducted based on secondary sources. These secondary data has been gathered from a number of books, office files, publications, records, annual reports and statements of banks and some research papers as well as some web sites.

\subsection{Information Obtained}

Different types of information is obtained from all the banks to prepare this report such as the target importers within the country border, the number and the value of $\mathrm{L} / \mathrm{C}$ opened on a certain time period and respective inflation rate. All of the collected information is within five consecutive years, i.e. 2006-2010. This information is segmented quarterly from January to March, April - June, July to September and October to December. The inflation rate is collected from some publications of Bangladesh Bank and the $\mathrm{L} / \mathrm{C}$ amount is processed using the total gross amount.

\subsection{Data Processing}

A careful and systematic process of data facilities comparison and renders it for further statistical analysis and interpretations. Data processing includes editing, classification and tabulation.

\subsection{Analysis \& Interpretation}

The collected data has been analyzed and interpreted to achieve the desired objective. MS Excel has been used for tabular and graphical presentation. Besides this, MS Word has been used to process all necessary research writing, charts, graph and tables. Correlation analysis, summation and average calculation are done through MS Excel \& the formula is used for analysis of correlation-

$$
\left[\mathrm{r}=\frac{\Sigma x y}{\sqrt{\Sigma x^{2} \times \Sigma y^{2}}}\right]
$$

\section{Data Analysis and Interpretation}

\subsection{Introduction}

The objective of this report is to analyze the impact of inflation rate on import trade. In this report, the fluctuation of inflation of inflation rate of different quarters of last five years are analyzed along with the number and financial volume of $\mathrm{L} / \mathrm{C}$ at the respective quarter. In this report, import trend analysis means the analysis of the number and financial volume of L/C. This analysis may help in understanding different factors of foreign trade. Information was collected on every imported item of Prime Bank Limited, Khulna branch from January 2006 to December 2010. Analysis has been done by using bar chart, line chart and correlation analysis.

The foreign exchange department of Khulna branch of PBL plays a significant role by providing different services to customers like advising import and export $\mathrm{L} / \mathrm{C}$, facilitate back-to-back $\mathrm{L} / \mathrm{C}$, foreign remittance transfer, foreign currency endorsement, locker etc. Import section of Prime Bank Limited remain very busy as our economy is very much dependent on import and there are many importers in Khulna and Jessore region and many of them are the client of Prime Bank Limited.

\subsection{Importers of Bangladesh}

The foreign exchange activities of import start with opening letter of credit of the importers. The list below shows some of the major importers of Bangladesh who operate their trade through different banks: Major importers of Bangladesh are as follows

Wirenett Impex Ltd., Wintrade, Winshine Corporation, Trade Navigation, Trade Mode Limited, TM International, The Tex Park Apparels, Texaco Corporation, Swift Solution, Stripe Trading Agency, Sterling Multi Technologies Ltd, Square Toiletries Ltd, Solar Trade, SNB Trading Co., Siam Fruit Agency, Shanta Consumer Products Ltd., Sea Shell Logistics Bangladesh, San Accessories Ltd., Safat Motors Ltd., Saba Corporation, Roman Group Bangladesh, Quality Automobiles, Retel, Prince Corporation Ltd., Maple International Ltd., M/s. Ahmed Brothers, Laskar Group. Juki Bangladesh Ltd., ISM Corporation, Interlink PLC, Index Trading Corporation, Foodex International, Delci Prokaushal Sangstha Ltd., Dallas Enterprise, Daffodil Computers Ltd., Crown Corporation, Bearing Sales Corporation, Al Hatim Refrigeration

Source: www.bizbangladesh.com/a2z-importers-list.php

The importers mainly import Fresh Fruits, Rice, Wheat, Dry Chilies, Sugar, Lentils, Onion, Garlic, Chick Peas, Soybean Extraction, pulse, cement raw materials, steel and iron, TSP, Printing Materials, and Accessories etc. While dealing with an import letter of credit, the banks have connection with different advising banks of different countries to contact with the relevant exporters. The most usual advising banks are ICICI Bank Kolkata India, UNION BANK OF INDIA, HSBC Bank Singapore, HSBC Bank Shanghai, Skandinaviska Enskilda, ICICI Bank Mumbai, Standard Chartered Bank Mumbai etc. The banks also have connection with different reimbursement banks like Citibank N. A., American Express Bank Ltd, Standard Chartered Bank, HSBC, Mashreq Bank etc.

\subsection{Transmitting the $L / C$}

After opening the Letter of Credit $(\mathrm{L} / \mathrm{C})$ in favor of the importer, banks transmit it to the advising bank for advising it to the beneficiary i.e. the exporter. The main copy is transmitted while a duplicate copy is reserved there for keeping own record. Banks generally transmit letter of credit through four methods:

- $\quad$ SWIFT

- (Society for Worldwide Inter-bank Financial Telecommunication)

- Telex

- Fax 


\section{- Courier}

\subsubsection{Payment System of Foreign Trade Procedure}

A number of banks use the following payment systems in the foreign trade procedure:

- Cash in advance system

- Documentary credit

\subsection{Fluctuation of Inflation Rate in Different Quarters}

Inflation of a country may fluctuate in each and every month, quarter or year. In calculating the inflation, consumer price index of a base year is taken as standard and the price of other years is compared with the price level of the base year. In case of Bangladesh, financial year 1995 - 1996 is considered as the base year. As my time limit is from 2006 to 2010 , that means last five years, here the trend of inflation rate for the last five years will be discussed.

For the clarification of the impact of inflation on import, each year is divided into 4 quarters. Quarterly inflation rates of Bangladesh were as follows:

Table 1. Quarterly inflation rate of Bangladesh

\begin{tabular}{cccccc}
\hline & $\mathbf{2 0 0 6}$ & $\mathbf{2 0 0 7}$ & $\mathbf{2 0 0 8}$ & $\mathbf{2 0 0 9}$ & $\mathbf{2 0 1 0}$ \\
\hline $1^{\text {st }}$ Quarter & 7 & 6.9 & 9.6 & 10.2 & 4.6 \\
$2^{\text {nd }}$ Quarter & 7.1 & 6.1 & 11.6 & 6 & 8.51 \\
$3^{\text {rd }}$ Quarter & 6.2 & 7.4 & 10.1 & 5 & 7.46 \\
$4^{\text {th }}$ Quarter & 7.5 & 9.2 & 10 & 2.3 & 7.56 \\
\hline
\end{tabular}

Source: www.bangladeshbank.org

Quarterly fluctuation of inflation rate can be presented graphically as below:

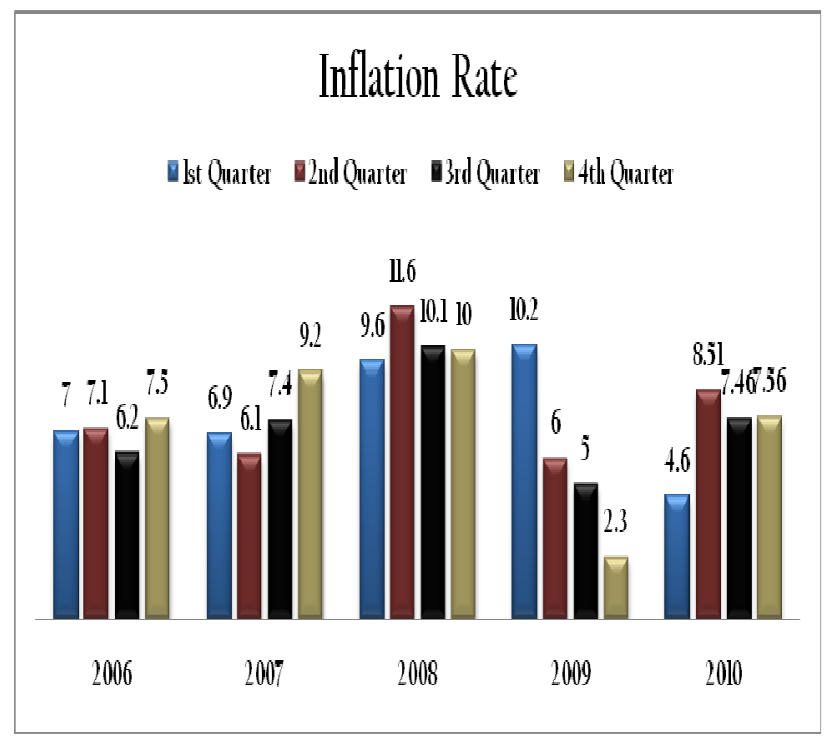

Figure 1. Inflation Rate (January 2006-December 2010)

From the above graph, it is seen that the inflation rate for the first two quarter of 2006 is steady. At the third quarter of 2006 , inflation rate had a downward trend but shortly after that, at the fourth quarter of 2006, it raised again. After the last quarter of 2006, inflation rate showed a good sign. That means, in the first two quarter of 2007, inflation rate showed a continuous downward trend. But after that, it showed a continuous upward trend for a long time. From the third quarter of 2007, it started to rise. The rising trend continued and picked at the $2^{\text {nd }}$ quarter of 2008 . At that time, inflation rate reached at the double digit $(11.6 \%)$. After the $2^{\text {nd }}$ quarter of 2008, the fluctuation of inflation rate was less frequent for the next three quarters but still remained double digit inflation rate. After the first quarter of 2009, the inflation rate was sharply reduced and it showed a continuous downward trend for the next three quarters and showed the lowest quarterly inflation rate among the five years in the last quarter of 2009. But, shortly after that it increased by two times at the $1^{\text {st }}$ quarter of 2010 and the rate of increase remained upward in the second quarter of 2010. But at the last two quarters of 2010, it showed a steady rate of inflation again.

\subsection{Trend in Number of L/C Opened in Different Quarter}

It is very natural that importers do not import the same quantity or volume of product in each and every year. It fluctuates and it is obvious. The fluctuation of the number of $\mathrm{L} / \mathrm{C}$ opened in a particular bank branch in different quarters of the last five years can be shown graphically as below:

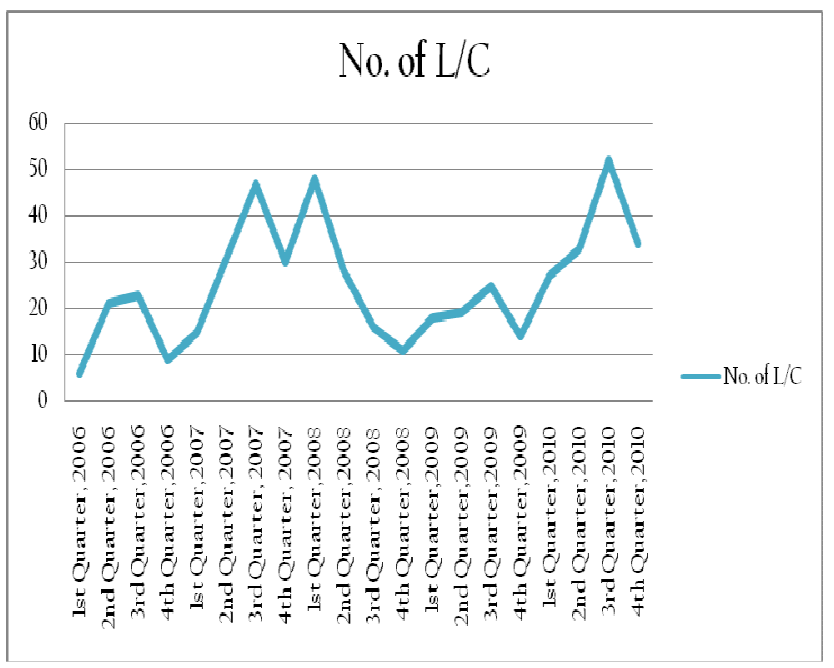

Figure 2. Number of $L / C$ in different quarters

From the above graph, it can be seen that the number of $\mathrm{L} / \mathrm{C}$ opened in different quarter of the last 5 years fluctuates rapidly. From the very beginning of the first quarter of 2006 , it showed a rapid upward trend in the number of $\mathrm{L} / \mathrm{C}$ opened. The trend continued for the next two quarter but at the last quarter of 2006, it showed a rapid downward trend. But after that, it started to increase rapidly for the next three quarters but dropped slightly for the next quarter. Again it showed an upward trend for the next quarter. But after the second quarter of 2008, it showed a continuous downward trend for the next three quarter. After that the curve showed a slight upward trend in the number of L/C opened but it fluctuated 
rapidly. After the third quarter of 2009, it showed a downward trend again but after that it continued to rise and reached at the peak among the last five years at the third quarter of 2010. But at the last quarter of 2010, it had fallen again.

\subsection{Trend in $L / C$ Value in Different Quarter}

Now, let us have a look on the trend of $\mathrm{L} / \mathrm{C}$ value that was opened on that particular bank during the last five years. The graphical representation is as below:

The trend of $\mathrm{L} / \mathrm{C}$ value showed a steady upward trend from the beginning of first quarter of 2006 .

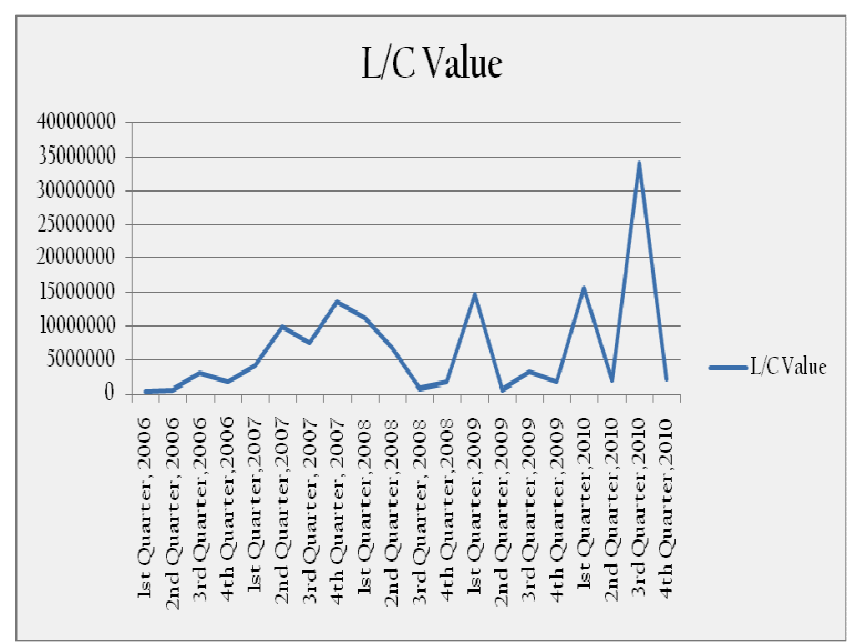

Figure 3. $L / C$ value in different quarters

It remained upward for a long time (till $2^{\text {nd }}$ quarter of 2007), but after that, it showed a slight downward trend for just one quarter. But after that, it again showed upward trend for the last quarter of 2007. But after that, the trend showed a continuous downward trend. After the $3^{\text {rd }}$ quarter of 2008 , it showed an upward trend again in the last quarter of 2008 and first quarter of 2009. But from the $2^{\text {nd }}$ quarter of 2009 , the fluctuation is noticeable. After the first quarter of 2009, it showed a rapid downward trend in the second quarter of 2009. After that, the trend showed a straight increase in L/C value at the $3^{\text {rd }}$ quarter of 2009 but again straight downward trend in the last quarter of 2009. But at the first quarter of 2010, it showed a rapid upward trend and just after that again it showed a rapid downward trend in the $2^{\text {nd }}$ quarter of 2010 . At the $3^{\text {rd }}$ quarter of $2010, \mathrm{~L} / \mathrm{C}$ value peaked at the top among the last 5 years but it dropped sharply at the last quarter of 2010 .

\subsection{Relationship between Number of $L / C$ and Inflation Rate}

Now, let us have a look about the fluctuation of the number of $\mathrm{L} / \mathrm{C}$ at different quarter of different year when inflation rate fluctuates. We can show the comparison graphically as below:

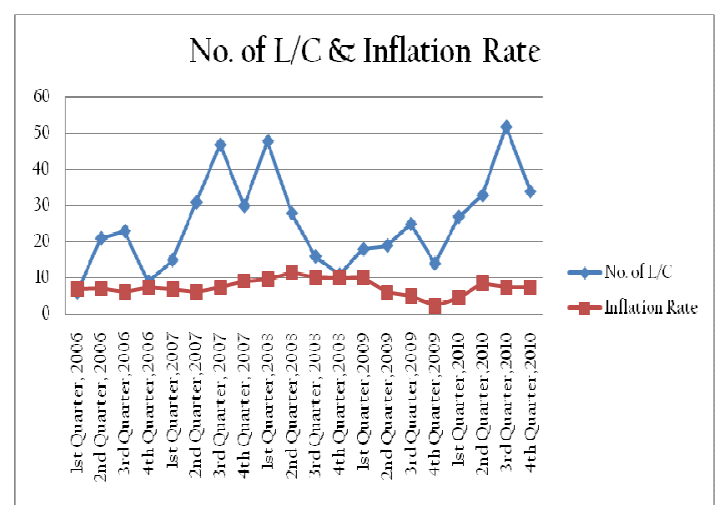

Figure 4. Number of $L / C$ and Inflation trend in different quarters

From the above chart, we can see that there is no strict correlation between inflation rate and number of $\mathrm{L} / \mathrm{C}$ opened. At the very $1^{\text {st }}$ quarter, when inflation rate was $7 \%$, then only $6 \mathrm{~L} / \mathrm{Cs}$ were opened. But at the $2^{\text {nd }}$ quarter of 2006 , when inflation rate curve moves slightly upward, then the inflation rate curve moved upward dramatically. Again at the $3^{\text {rd }}$ quarter of 2006, inflation rate curve showed downward movement, but still number of L/C curve showed slight upward movement. At the last quarter of 2006, when inflation rate curve moves upward, number of $\mathrm{L} / \mathrm{C}$ curve moves downward dramatically. Again at the $1^{\text {st }}$ quarter of 2007, inflation curve showed downward movement, but number of L/C curve showed slight upward movement. But at the second quarter of 2007, when inflation curve showed slight downward movement, number of L/C curve showed upward movement. But, paradoxically, when inflation rate curve showed slight upward movement, number of L/C curve showed remarkable upward movement at the $3^{\text {rd }}$ quarter of 2007. Again although inflation rate curve showed upward movement at the last quarter of 2007, number of L/C curve showed downward movement. At the $1^{\text {st }}$ quarter of 2008 , the curve showed that number of L/C increased along with the rising inflation rate. But in the next quarter, number of $\mathrm{L} / \mathrm{C}$ opened decreased dramatically when inflation rate rise. But for the next two quarters, when inflation rate curve falls slightly, number of L/C opened also decreased slightly. But, afterward, for the next 3 quarter, when inflation rate decreased continuously, L/C curve showed slight ups and downs trend. For the next two quarters, more L/Cs were opened when inflation rate were increased. But, in the next quarter, when inflation rate falls slightly, number of $\mathrm{L} / \mathrm{C}$ curve shows the highest upward movement. But, at the last quarter of 2010, when inflation rate increased slightly, number of $\mathrm{L} / \mathrm{C}$ opened decreased dramatically.

Further, the value of the correlation of co-efficient between the number of $\mathrm{L} / \mathrm{C}$ opening and quarterly inflation rate is 0.125855684 (see appendix). As it shows positive value, that means if inflation rate increases, then number of $\mathrm{L} / \mathrm{C}$ opening will also increase. But as the correlation of co-efficient of the number of $\mathrm{L} / \mathrm{C}$ opening and quarterly inflation rate is less than 0.5 which states low degree of correlation between them. 


\subsection{Relationship between L/C Value and Inflation Rate}

Now, let us have a look on the quarterly comparison between the fluctuations of inflation rate and $\mathrm{L} / \mathrm{C}$ value. In 2006, the graphical representation of inflation rate and $\mathrm{L} / \mathrm{C}$ value was as below:

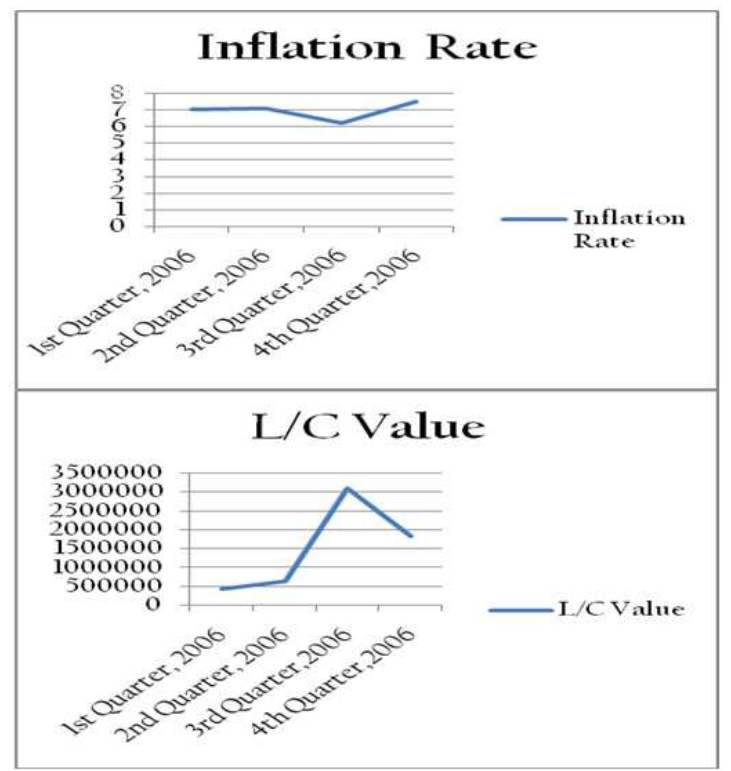

Figure 5. Inflation rate and $L / C$ value trend in 2006

From the figure, we can see that, at the $1^{\text {st }}$ two quarters of 2006, when inflation rate increased slightly, then financial volume of $\mathrm{L} / \mathrm{C}$ were also increased. But, at the $3^{\text {rd }}$ quarter of 2006, when inflation rate falls, then more L/C was opened. Again at the last quarter of 2006, when inflation rate curve showed an upward movement, then $\mathrm{L} / \mathrm{C}$ value curve showed downward movement.

In 2007, the fluctuations were as below:

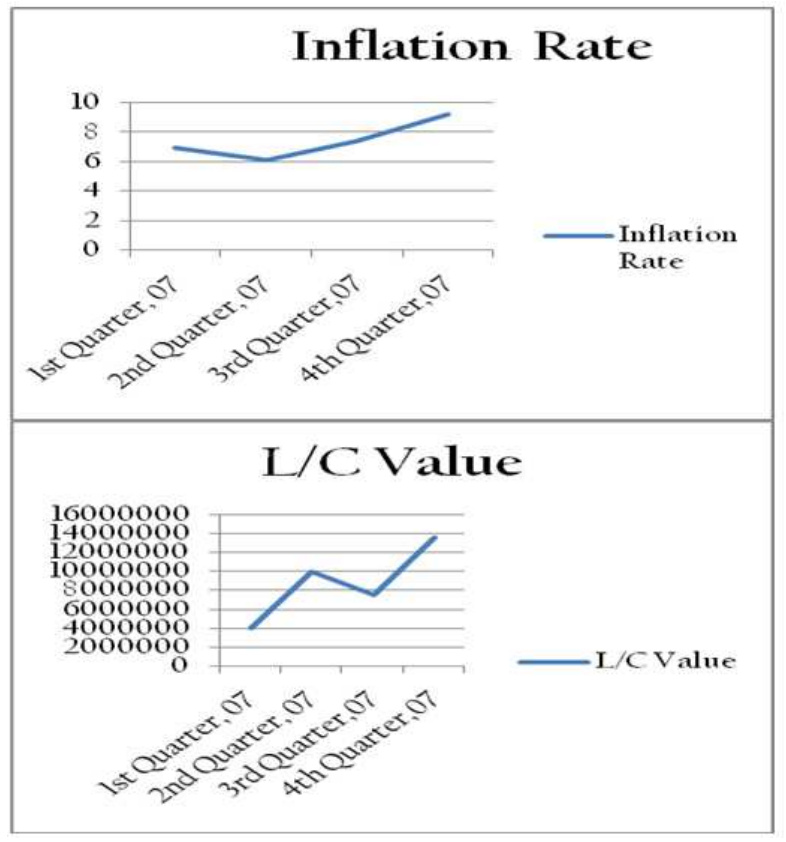

Figure 6. Inflation rate and $L / C$ value trend in 2007
From the $1^{\text {st }}$ quarter to $2^{\text {nd }}$ quarter of 2007 , inflation rate decreased, but L/C value curve showed an upward movement. But, after the $2^{\text {nd }}$ quarter of 2007 , inflation rate curve showed a steady upward movement, but at that time, $\mathrm{L} / \mathrm{C}$ value curve showed a downward trend in the $3^{\text {rd }}$ quarter of 2007 and an upward trend in the last quarter.

In 2007, the fluctuations were as below:

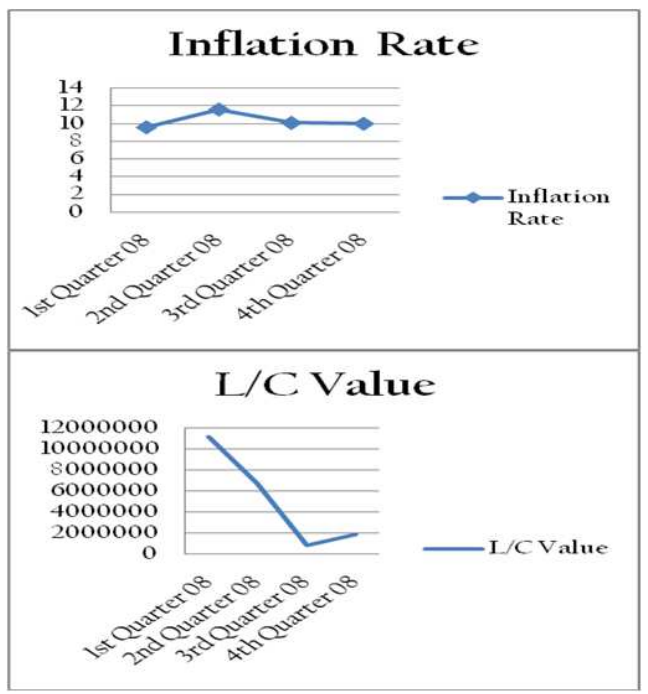

Figure 7. Inflation rate and $L / C$ value trend in 2008

In case of 2008, when inflation rate increased from the first quarter to $2^{\text {nd }}$ quarter, then lesser $\mathrm{L} / \mathrm{C}$ were opened for importing goods. But, after the $2^{\text {nd }}$ quarter of 2008 , when inflation rate decreased steadily, $\mathrm{L} / \mathrm{C}$ value had fallen dramatically in the $3^{\text {rd }}$ quarter but shows a slight upward movement at the end of 2008.

In 2009, the graphical trend are as below:

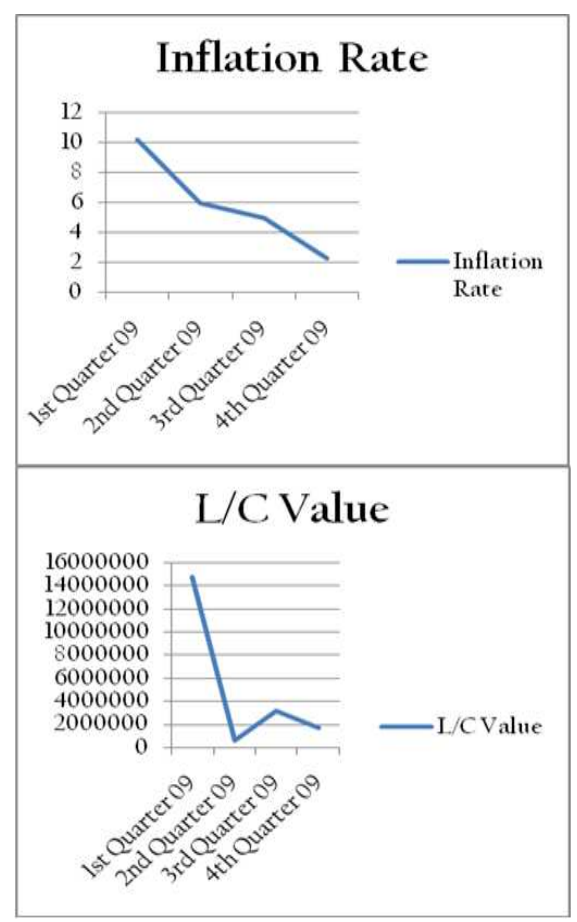

Figure 8. Inflation rate and L/C value trend in 2009 
Now, we can see the steady downward trend of inflation rate at every quarter of 2009 . But $\mathrm{L} / \mathrm{C}$ value curve showed a straight downward trend at the second quarter. $\mathrm{L} / \mathrm{C}$ value increased slightly at the $3^{\text {rd }}$ quarter but again falls at the $4^{\text {th }}$ quarter of 2009.

In 2010, the trend shows the following graphical movement

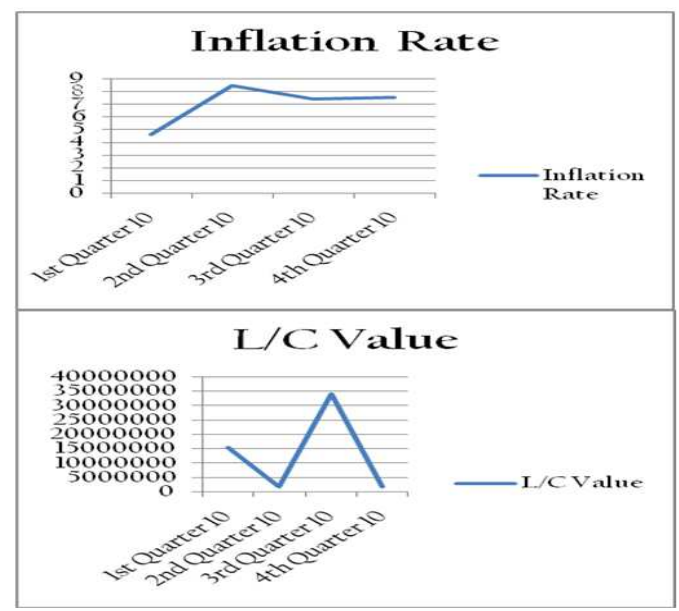

Figure 9. Inflation rate and $L / C$ value trend in 2010
In 2010, the relationship between inflation rate and $\mathrm{L} / \mathrm{C}$ value showed the most irregular trend. When inflation rate increased from the $1^{\text {st }}$ quarter of 2010 to the $2^{\text {nd }}$ quarter of 2010, then L/C value falls down remarkably. But, after the $2^{\text {nd }}$ quarter, inflation rate curve falls in the $3^{\text {rd }}$ quarter and an insignificant rise in the last quarter of 2010. But, at the same time, L/C value rise significantly in the $3^{\text {rd }}$ quarter and again falls significantly at the end of 2010 .

\subsection{Relationship between Import in Different Sectors and Inflation Rate}

It is very natural that importers do not import the same quantity or volume of product in each and every year rather it fluctuates. In addition to that, imports vary for different sectors like- Consumer goods, intermediate goods. Industrial raw materials, capital machinery and such others.

The fluctuation of sector wise import during the last five years can be shown graphically as below:

Table 2. Import in different sectors from 2006-2010

\begin{tabular}{|c|c|c|c|c|c|}
\hline Particular & 2006 & 2007 & 2008 & 2009 & 2010 \\
\hline Consumer goods & 1182.46 & 1748.95 & 3473.45 & 2116.49 & 3404.11 \\
\hline Intermediate goods & 1252.15 & 1525.2 & 2042.24 & 2223.99 & 2332.63 \\
\hline Industrial raw material & 5838.98 & 6437.08 & 9017.88 & 8553.91 & 10057.83 \\
\hline Capital machinery & 1493.56 & 1512.38 & 1753.74 & 1234.99 & 1918.62 \\
\hline $\begin{array}{l}\text { Machinery for miscellaneous } \\
\text { industry }\end{array}$ & 1134.12 & 1214.62 & 1631.54 & 1870.08 & 2533.64 \\
\hline $\begin{array}{l}\text { Petroleum and Petroleum } \\
\text { products }\end{array}$ & 2018.84 & 2364.84 & 2576.7 & 1864.56 & 2366.53 \\
\hline Others & 2325.23 & 2647.98 & 3940.04 & 3938.72 & 6043.6 \\
\hline Total & 15245.3 & 17451.1 & 24435.6 & 21802.7 & 28657 \\
\hline
\end{tabular}

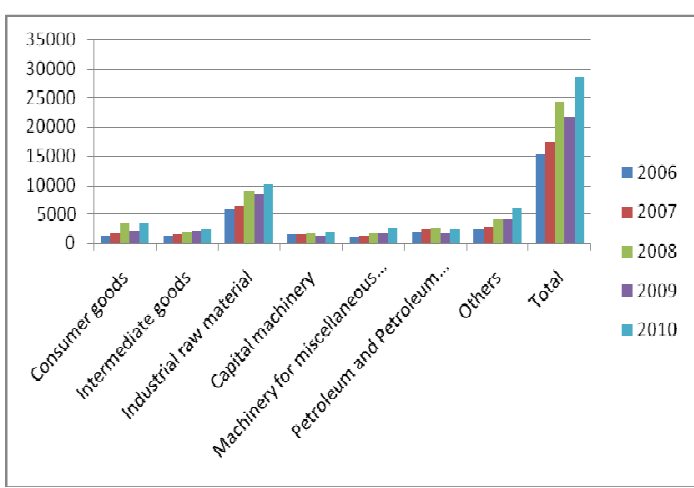

Figure 10: Sector wise import in Bangladesh.

From the above graph, we see that the amount of imports is on an upward trend while the years pass by. Regardless the inflation rate, and depending on the demand it varies. For example, in 2008, while the inflation rate was on a peak, import was also higher than the previous year. And once again when the inflation rate falls in 2009 import also fell. But when inflation rate was at a moderate level in 2006 import was lowest.

\subsection{Reasons for Insignificant Relationship}

Inflation of a country is not the sole factor that can affect the import business of a country. There are so many factors that can affect the insignificant relation between inflation and import business.

Exchange rate of Bangladeshi taka to US dollar can play a vital role in import business. When exchange rate decreased, that means Bangladeshi taka value become stronger against US dollar value. That means importers can purchase more with the Bangladeshi taka than the period when US dollar value was stronger.

Another reason may be the natural disaster of Bangladesh. Each and every year, Bangladesh faces some severe natural disasters that results in less harvest available for the population of Bangladesh. That's why Bangladesh has to import more and more goods, especially food grain to meet up the demand of the domestic market. For this reason, importers have to import more and more, regardless whatever the inflation rate is.

Another cause is the increasing price all over the global 
market. Price of different goods rose over the last decade. As Bangladesh is a net importer country, so there is no other option other than importing goods although the price is high in the international market.

Different government policies and relationship with the exporter country can play a vital role in the insignificance in relationship between inflation rate and import. The more favorable government policies for import trade, the healthy import business for the country.

Finally, the main problem, the population problem of Bangladesh, plays a vital role on the import figure of Bangladesh. Increasing population of this shortly developing country creates a huge pressure on the demand of various goods. Domestic production becomes insufficient to meet up that demand. As a result, to survive, importers have to import those goods whatever the inflation rate is.

\section{Findings}

Foreign trade activities of banking sector depends on a lot of factors like economic condition of a country, productivity, rules and regulations imposed by the government, political unsteadiness of a country and so on. Another important factor, which is an internal factor and which can affect the foreign trade activity of a bank greatly is the quality of services offered by the bank and the location of the bank. After analyzing the five-year trend of foreign trade activities of different banks and the inflation rate fluctuation, the findings of the study can be summarized as below:

- The value of the correlation of co-efficient between the number of L/C opening and quarterly inflation rate shows positive value that means if inflation rate increases, then number of $\mathrm{L} / \mathrm{C}$ opening will also increase. But as the value correlation of co-efficient of the number of $\mathrm{L} / \mathrm{C}$ opening and quarterly inflation rate states that there is a low degree of correlation between them.

- The value of the correlation coefficient between volume of $\mathrm{L} / \mathrm{C}$ opening and quarterly inflation rate also shows positive value which indicates that they have positive association between them but the value says the relation is at a minimum level. That means if the inflation rate increases then the volume of $\mathrm{L} / \mathrm{C}$ opening will increase but very insignificantly.

- Inflation rate of a country is not the only determinant of the foreign trade of that country. There are a lot of factors that can affect the volume of foreign trade of a country. In case of Bangladesh, the dominance of other factors like exchange rate, market demand, interest rate, natural disasters, population etc. can be much more powerful than the inflation rate. That's why the relationship between inflation rate and import trade shows an insignificant relation.

\section{Conclusion}

There is no country in this world which is completely self - sufficient. Each and every country has to be dependent on other countries for the goods and services which has an extra demand in domestic market or which has no substitute in that country. Export - import relationship among the countries is growing up rapidly. But foreign trade is a vast mechanism. It is very difficult to understand. This report has an attempt to explain the foreign trade procedure briefly. The main objective of this report is to find out whether fluctuation of inflation rate has any effect on import business or not. But from the study, it is noticeable that inflation has a little impact on import which is very insignificant. Import of a country doesn't rely only on inflation. Rather it is influenced by the economic stability, market demand, presence of adequate substitute; relationship with the exporting countries etc. inflation rate fluctuation is not a significant factor which can make the importers anxious.

\section{References}

[1] Gupta, S.P \& Gupta, M.P (2003) "Business Statistics", Sultan Chand $\&$ Sons Publications, $12^{\text {th }}$ Edition.

[2] Kothari C.R., (2004) "Research Methodology", New Age International Publications, $2^{\text {nd }}$ Edition.

[3] Samuelson P. A. and Nordhaus W. D.(2005) Economics, $18^{\text {th }}$ edition, McGraw-Hill

[4] Ahmed S. and Mortaza M. G. (2005), "Inflation and Economic Growth in Bangladesh: 1981-2005", Policy Analysis Unit, Bangladesh Bank, Working Paper Series: WP 0604, pp 4-5.

[5] Akhtaruzzaman Md. (2005), "Inflation in the Open Economy: An Application of the Error Correction Approach to the Recent Experience in Bangladesh", Policy Analysis Unit, Bangladesh Bank, Working Paper Series: WP 0602, pp 3-5.

[6] Farah N. and Mortaza M. G. (2009), "Estimating Inflation Rates of Import-Concentrated Commodities", Policy Analysis Unit, Bangladesh Bank, Policy Note Series: PN 0902, pp. 6-8.

[7] Khanom R. \& Rahman M. M. "The Causative Factors of Inflation in Bangladesh: An Economic Study", Chittagong University Studies, Social Science, Vol. XVI, No. 1, pp. 101 -105 .

[8] Mortaza M. G (2006), "Sources of Inflation in Bangladesh: Recent Macroeconomic Experience", Policy Analysis Unit, Bangladesh Bank, Working Paper Series: WP 0704, pp. 3-5.

[9] Rahman H. and Mortaza M. G. (2008), "Transmission of International Commodity Prices to Domestic Prices in Bangladesh", Policy Analysis Unit, Bangladesh Bank, Working Paper Series: WP 0807, pp. 11-17.

[10] Rahman M. (2010), "State of the Bangladesh Economy in FY2009-10: Second Reading, Dhaka: Centre for Policy Dialogue", pp. 8-12.

[11] www.primebank.com.bd 
[12] www.businessdictionary.com

[13] www.wikipedia.com
[14] www.bangladeshbank.org.bd

[15] www.financialexpress.com 